International Journal of Agriculture, Environment and Bioresearch

Vol. 06, No. 03; 2021

ISSN: $2456-8643$

\title{
EDAPHOCLIMATIC DIVERSITY AND ECOLOGICAL DESCRIPTORS OF Guadua BAMBOO SPECIES (Poaceae: Bambusoideae) IN MEXICO
}

\author{
Gabriela Ramírez-Ojeda1 ${ }^{1}$, Gabriela Orozco-Gutiérrez ${ }^{2 *}$, Luis Ángel Barrera-Guzmán ${ }^{3}$ and Eduardo Ruiz- \\ Sanchez ${ }^{4}$ \\ ${ }^{1}$ Experimental Field Centro Altos de Jalisco, National Research Institute of Agricultural, Forestry and Livestock \\ Research, Tepatitlán de Morelos, Jalisco, México. \\ ${ }^{2 *}$ Experimental Field Tecomán, National Research Institute of Agricultural, Forestry and Livestock Research, \\ Tecomán, Colima, orozco.gabriela@inifap.gob.mx \\ ${ }^{3}$ Phytotechnics Department, Chapingo Autonomous University, Texcoco, México, México. \\ ${ }^{4}$ Department of Botany and Zoology, University Center for Biological and Agricultural Sciences, University of \\ Guadalajara, Zapopan, Jalisco, México. \\ https://doi.org/10.35410/IJAEB.2021.5641
}

\begin{abstract}
Conservation and sustainable use require the description of the environments where species develop. The objectives of this research were:1) determine edaphoclimatic diversity patterns and ecological descriptors associated with geographic distribution of species of Guadua and, 2) identify the climatic variables of greatest importance for distribution and environmental similarity between seven Mexican bamboo species. Using 192 accessions and an environmental information system composed of 40 edaphoclimatic variables in raster format with spatial resolution of $1 \mathrm{~km}^{2}$, diversity patterns of distribution areas of each specie were identified, as well as ecological descriptors through the use of Geographic Information Systems tools. Influence of edaphoclimatic variables on the geographical distribution was determined by multivariate techniques using Principal Component Analysis and Cluster Analysis. In distribution areas of accessions considered, seven climatic types were identified, predominantly tropical, monsoon (Am) and tropical, Savannah (Aw) and 12 soil units, predominantly vertisol. Principal component analysis determined that eight variables were the most important to determine the geographic distribution of these accessions. In addition, cluster analysis identified six groups of species according to their similarity. Information about edaphoclimatic conditions and the environmental breadth of the distribution of seven Mexican native bamboo species was provided.
\end{abstract}

Keywords: Multivariate analysis, ecological descriptors, edaphoclimatic diversity, native bamboo species, Guaduinae.

\section{INTRODUCTION}

Bamboo is part of the first "Kit" of tools of humanity ${ }^{[1]}$. The use of bamboo in Mexico has preHispanic antecedents, used by various ethnic groups such as: Totonacas, Huastecos, Aztecas, Teotihuacanos and Maya-Chontales ${ }^{[2]}$. Bambusoideae subfamily is the third most diverse of the Poaceae family with more than 1,680 species described worldwide ${ }^{[3,4,5]}$. Neotropical woody bamboos are classified into three subtribes, one of them is Guaduinae, with 60 species ${ }^{[5,6,7,8,9]}$. 
Vol. 06, No. 03; 2021

ISSN: $2456-8643$

The geographical limits of this subtribe extend from Mexico to Argentina and the West Indies ${ }^{[7}$, 9].

Ruiz-Sanchez et al. $(2015){ }^{[8]}$ registered 50 native species of woody bamboo and four herbaceous bamboo, which 33 are endemic to Mexico. On the other hand, Dávila et al. (2018) ${ }^{[10]}$ cited 62 species of woody and herbaceous bamboo, and 32 are reported as endemic to Mexico. Finally, Ruiz-Sanchez et al. (2020) ${ }^{[11]}$ reported 51 species of native woody bamboo ${ }^{[12]}$. To the list of 52 native species of woody bamboo, four more were added, one of them from the genus Rhipidocladum, another from the genus Otatea and two more from Chusquea genus ${ }^{[13,14,15] .}$ The most recent list includes 56 species of woody bamboo, with 39 of them endemic to Mexico. The Guaduinae subtribe is the most important culturally and economically for Mexico.

Guadua is the most important genus of bamboos in America, endemic to this continent and composed of 33 species. The Guadua genus in America, present in a great variety of habitats, is the most commercially used, mainly in construction, due to its hardness and the arrangement of its fibers, and it is considered the structural bamboo by excellence. In addition, Guadua species are the largest and the leafiest of the American bamboos ${ }^{[16]}$.

Species of Guadua in Mexico are distributed in the following biogeographic regions: Veracruzana, Lowlands of the Pacific, Tamaulipas, High areas of Chiapas, Sierra Madre Oriental and Sierra Madre del Sur ${ }^{[11]}$. The seven native Mexican species of Guadua considered in this research are: G. aculeata Rupr. ex Fourn., G. amplexifolia J. Presl., G. inermis Rupr. ex Fourn., G. longifolia (E. Fourn.) R.W. Pohl, G. paniculata Munro, G. tuxtlensis Londoño \& RuizSanchez and G. velutina Londoño \& L.G. Clark ${ }^{[11,12]}$.

Ecogeographic studies of plant genetic resources allow to identify the adaptive ranges of the species and most relevant environmental variables that define their distribution ${ }^{[17]}$. Its main applications are related to the collection, conservation, characterization, documentation and use of plant genetic resources ${ }^{[18,19,20,21,17,22]}$. Additionally, with the use of ecological descriptors derived from geographic location of germplasm and environmental maps obtained through GIS tools ${ }^{[23,21,24]}$, it is possible to predict the environmental conditions of the accession sites ${ }^{[25,21]}$. The objectives of this research were determining the edaphoclimatic diversity patterns and ecological descriptors associated with the geographic distribution of seven native bamboo species of Guadua genus, and identify the most important climatic variables for distribution and environmental similarity between Mexican Guadua species.

\section{MATERIALS AND METHODS}

\subsection{Accession database}

For the present study, a database was built with information from georeferenced accessions of seven native bamboo species (G. aculeata, G. inermis, G. amplexifolia, G. longifolia, G. paniculata, G. tuxtlensis and G. velutina) with information from national ${ }^{[26]}$ and international ${ }^{[27]}$ inventories as well as scientific articles ${ }^{[11]}$.

All records were reviewed in order to eliminate atypical data such as records with little geographic precision, repeated data, and accessions outside the study area, which were eliminated, thus forming a database with 192 collections distributed in Mexico (Figure 1). 


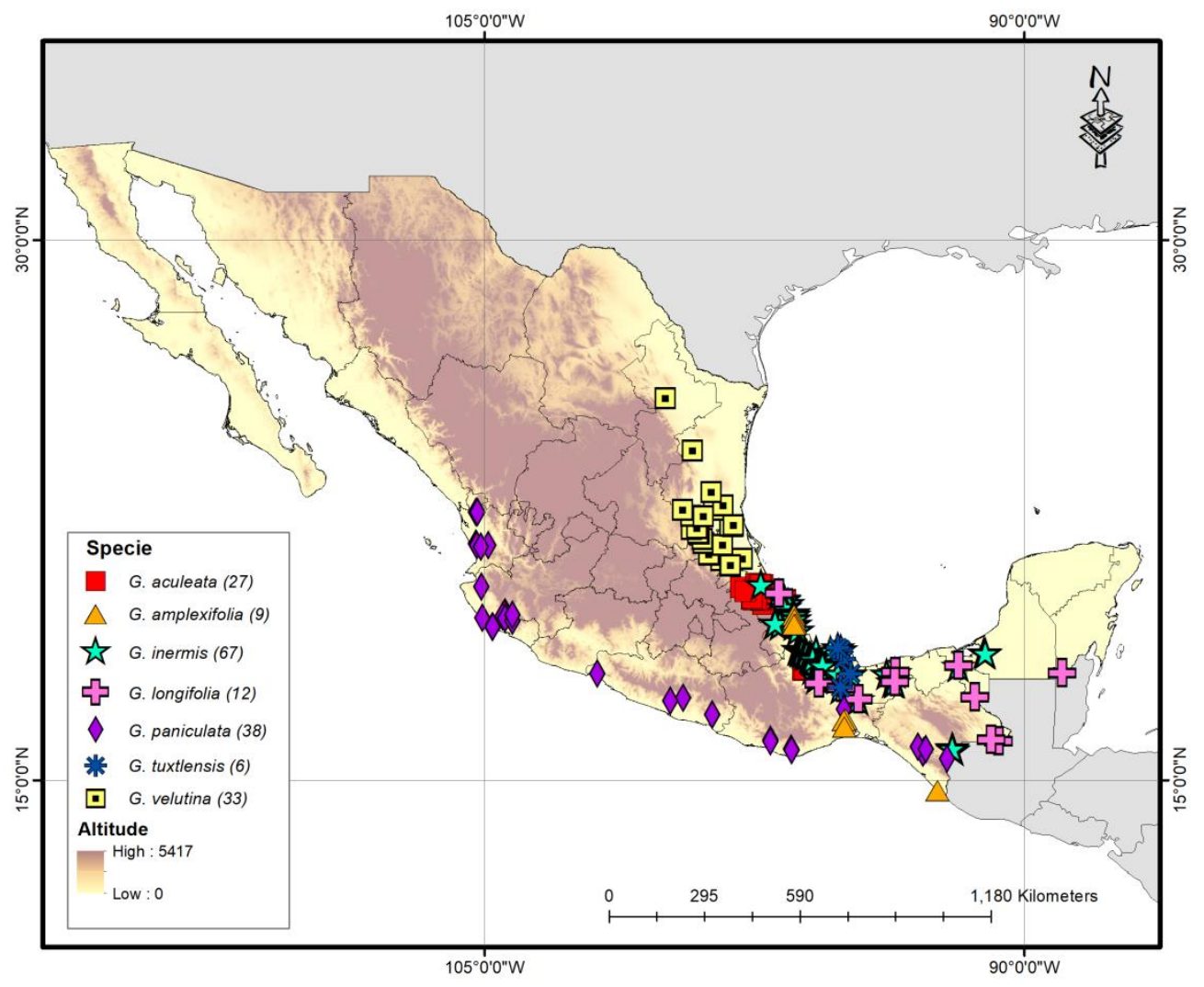

Figure 1: Geographic distribution of seven accessions of Guadua species in Mexico.

\subsection{Edaphoclimatic information system}

The environmental information system was built with 21 climatic variables and 19 edaphic variables. Nineteen of the climatic variables correspond to the bioclimatic variables of WorldClim version 2.1 corresponding to the climatic period 1970-2000 with spatial resolution of $\sim 1 \mathrm{~km}^{2[28]}$ : annual mean temperature $\left(\mathrm{BIO} 1,{ }^{\circ} \mathrm{C}\right)$, mean diurnal range $\left(\mathrm{BIO} 2,{ }^{\circ} \mathrm{C}\right)$, isothermality (BIO3, BIO2/BIO7*100), temperature seasonality (BIO4, standard deviation*100), max temperature of the warmest month (BIO5, $\left.{ }^{\circ} \mathrm{C}\right)$, min temperature of coldest month $\left(\mathrm{BIO} 6,{ }^{\circ} \mathrm{C}\right)$, temperature annual range (BIO7, BIO5-BIO6), mean temperature of wettest quarter $\left(\mathrm{BIO} 8,{ }^{\circ} \mathrm{C}\right)$, mean temperature of driest quarter $\left(\mathrm{BIO} 9,{ }^{\circ} \mathrm{C}\right)$, mean temperature of warmest quarter (BIO10, ${ }^{\circ} \mathrm{C}$ ), mean temperature mean of coldest quarter $\left(\mathrm{BIO} 11,{ }^{\circ} \mathrm{C}\right)$, annual precipitation $(\mathrm{BIO} 12, \mathrm{~mm})$, precipitation of wettest month $(\mathrm{BIO13}, \mathrm{mm})$, precipitation of driest month (BIO14, mm), precipitation seasonality (BIO15, coefficient of variation), precipitation of wettest quarter (BIO16, mm), precipitation of driest quarter $(\mathrm{BIO} 17, \mathrm{~mm})$, precipitation of warmest quarter (BIO18, $\mathrm{mm}$ ) and precipitation of coldest quarter $(\mathrm{BIO19}, \mathrm{mm})$.

Altitude (ALT, masl) of the site of each accession was determined from an elevation model in raster format with spatial resolution $\sim 1 \mathrm{~km}^{2}{ }^{28]}$. Finally, annual evapotranspiration (ET, mm) 
Vol. 06, No. 03; 2021

ISSN: $2456-8643$

was calculated from the monthly values in raster format with the same spatial resolution as the rest of the variables ${ }^{[29]}$.

Edaphic variables used were percentage of gravel (GR, \%), sand (SA, \%), silt (SI, \%) and clay $(\mathrm{CL}, \%)$, bulk density $\left(\mathrm{BD}, \mathrm{kg} / \mathrm{dm}^{3}\right)$, organic carbon $(\mathrm{CO}, \%), \mathrm{pH}$, base saturation (BS, \%), TEB $\left(\mathrm{cmol} / \mathrm{kg}\right.$ ), calcium carbonate $\left(\mathrm{CACO}_{3}, \%\right)$, calcium sulfate $(\mathrm{CASO} 4, \%)$, salinity (SAL, $\mathrm{dS} / \mathrm{m}$ ) and sodium (SOD, \%). These variables were obtained from the world database in raster format called Harmonized World Soil Database version 1.1 with spatial resolution of $\sim 1 \mathrm{~km}^{2}$, developed in 2009 by the Food and Agriculture Organization of the United Nations (FAO), International Institute for Applied Systems Analysis (IIASA), International Soil Information and Reference Center (ISRIC- World Soil Information), Institute of Soil Sciences- Chinese Academy of Sciences (ISS-CAS) and the Common Center for European Commission Research ${ }^{[30]}$.

\subsection{Ecological descriptors}

Ecological descriptors of each variable for each bamboo species, was calculated using the methodology proposed by Ruiz-Corral et al. (2008) [21]. For this, the vectors with the geographical coordinates of each accession were used to obtain the point values of each variable through the use of GIS tools. The information was concentrated in a spreadsheet, where the extreme values (minimum and maximum), and mean value of each variable for each species were subsequently determined ${ }^{[24,22]}$.

\subsection{Edaphoclimatic diversity}

The diversity of climate and soil types were determined through a vector made with the database of accessions of bamboo species and environmental variables with the use of GIS tools. For this, the point value of each climatic type and soil unit was extracted for each accession, where the frequencies of each category by species were subsequently identified. Climatic types of accessions sites were defined from the world climatic classification with the Köppen-Geiger

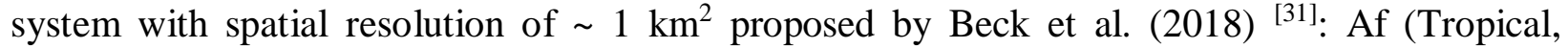
rainforest), Am (Tropical, monsoon), Aw (Tropical, Savannah), BWh (Arid, deser, hot), BWk (Arid, desert, cold), BSh (Arid, steppe, hot), BSk (Arid, steppe, cold), Csa (Temperate, dry summer, hot summer), Csb (Temperate, dry summer, warm summer), Csc (Temperate, dry and cold summer), Cwa (Temperate, dry winter, hot summer), Cwb (Temperate,dry winter, warm summer) Cwc (Temperate, dry winter, cold summer), Cfa (Temperate, no dry season, hot summer), $\mathrm{Cfb}$ (Temperate, no dry season, warm summer), Cfc (Temperate, no dry season, cold summer), Dsa (Cold, dry summer, hot summer), Dsb (Cold, dry summer, warm summer), Dsc (Cold, dry summer, cold summer), Dsd (Cold, dry summer, very cold Winter), Dwa (Cold, dry winter, hot summer), Dwb (Cold, dry winter, warm summer), Dwc (Cold, dry winter, cold summer), Dwd (Cold, dry winter, very cold winter), Dfa (Cold, no dry season, hot summer), Dfb (Cold, no dry season, warm summer), Dfc (Cold, no dry season, cold summer), Dfd (Cold, no dry season, very cold Winter), ET (Polar, tundra) and EF (Polar, Frost).

Soil units were obtained from the Harmonized World Soil database (2009) ${ }^{[30]}$ : Acrisol (AC), Alisol (AL), Andosol (AN), Arenosol (AR), Anthrosol (AT), Chernozem (CH), Calcisol (CL), Cambisol (CM), Fluvisol (FL), Ferralsol (FR), Gleysol (GL), Greysem (GR), Gypsisol (GY), Histosol (HS), Kastanozem (KS), Leptosol (LP), Luvisol (LV), Lixisol (LX), Nitosol (NT), 
Podzoluvisol (PD), Phaezem (PH), Planosol (PL), Plinthosol (PT), Podzol (PZ), Regosol (RG), Solonchak (SC), Solonetz (SN), Vertisol (VR).

\subsection{Statistical analysis}

Multicollinearity between variables of the environmental system was calculated through Pearson's correlation between pairs of variables, eliminating those with absolute coefficients > 0.95 . With the selected variables, a principal component analysis (PCA) was performed in Rstudio ${ }^{[32]}$. The selected variables were integrated into three groups referring to temperature, precipitation and those related to physicochemical soil factors (Table 1). The calculation of eigenvalues, eigenvectors and contribution of the variables of principal components were obtained with the FactoMineR ${ }^{[33]}$ and factoextra ${ }^{[34]}$ packages.

Table 1. Classification of edaphoclimatic variables used in multivariate analysis.

\begin{tabular}{|l|l|}
\hline Group & Variables \\
\hline I - Temperature & BIO1, BIO3, BIO4, BIO5, BIO6, BIO7, BIO11 and Altitude \\
\hline II - Precipitation & BIO12, BIO13, BIO15, BIO18, BIO19, ET \\
\hline III - Soil & Gravel, sand, silt, clay, BD, OC, pH, CEC, BS, CACO 3 , Salinity \\
\hline
\end{tabular}

Cluster analysis (CA) was performed with Euclidean distances and Ward's method of least variance to identify environmentally similar accessions. To verify if there is a tendency to clustering, Hopkins $(\mathrm{H})$ statistic was calculated with clustertend ${ }^{[35]}$, where values $\leq 0.5$ indicate a high tendency to clustering. The best algorithm for grouping (hierarchical and non-hierarchical methods) was calculated with clValid ${ }^{[36]}$. For the selection of the optimal number of groups, the NbClust package was used with the majority rule ${ }^{[37]}$. Finally, analysis of variance and Tukey mean comparisons were performed for the groups of species generated.

\section{RESULTS}

\subsection{Ecological descriptors and edaphoclimatic diversity}

The result of the ecological descriptors is shown in Table 2. For this, the mean annual temperature, annual precipitation, annual evapotranspiration and altitude were selected as the most important variables for the distribution of the species under study. 
Table 2. Ecological descriptors by bamboo species. ALT = altitude, BIO1= annual mean temperature, $\mathrm{BIO12}=$ annual precipitation and $\mathrm{ET}=$ annual evapotranspiration. $\mathrm{Max}=$ maximum, Min= minimum, Med $=$ average.

\begin{tabular}{|lccccccccccccc|}
\hline \multirow{2}{*}{ SPECIE } & \multicolumn{3}{c}{ ALT } & \multicolumn{4}{c}{ BIO1 } & \multicolumn{3}{c|}{ BIO12 } & \multicolumn{3}{c|}{ ET } \\
\cline { 2 - 13 } & Max. & Min. & Med. & Max. & Min. & Med. & Max. & Min. & Med. & Max. & Min. & Med. \\
\hline G. aculeata & 906 & 12 & 326 & 26.0 & 20.8 & 22.9 & 2719 & 1312 & 1889 & 1477 & 990 & 1261 \\
G. amplexifolia & 213 & 8 & 77 & 28.1 & 24.9 & 25.8 & 1438 & 1012 & 1140 & 1111 & 744 & 917 \\
G. inermis & 995 & 0 & 137 & 26.7 & 20.4 & 25.1 & 3656 & 1080 & 1616 & 1533 & 890 & 1126 \\
G. longifolia & 237 & 5 & 97 & 26.6 & 24.4 & 25.6 & 3656 & 1399 & 2303 & 1533 & 1166 & 1374 \\
G. paniculata & 1733 & 38 & 536 & 26.9 & 16.9 & 24.2 & 2479 & 910 & 1502 & 1260 & 632 & 1008 \\
G. tuxtlensis & 347 & 16 & 142 & 25.7 & 24.4 & 25.1 & 2453 & 1818 & 2040 & 1347 & 1202 & 1297 \\
G. velutina & 1016 & 2 & 238 & 25.3 & 21.1 & 23.8 & 2023 & 746 & 1434 & 1421 & 614 & 1088 \\
\hline
\end{tabular}

Figure 2 shows the distribution of four variables used for general ecological descriptors of seven bamboo species. In the figure, it is possible to identify areas of overlap between variables and species due to their geographical distribution. About altitudinal range of bamboo species, $G$. paniculata is the species that reaches higher altitudes, and G. amplexifolia is the species that is distributed at the lowest altitude above sea level

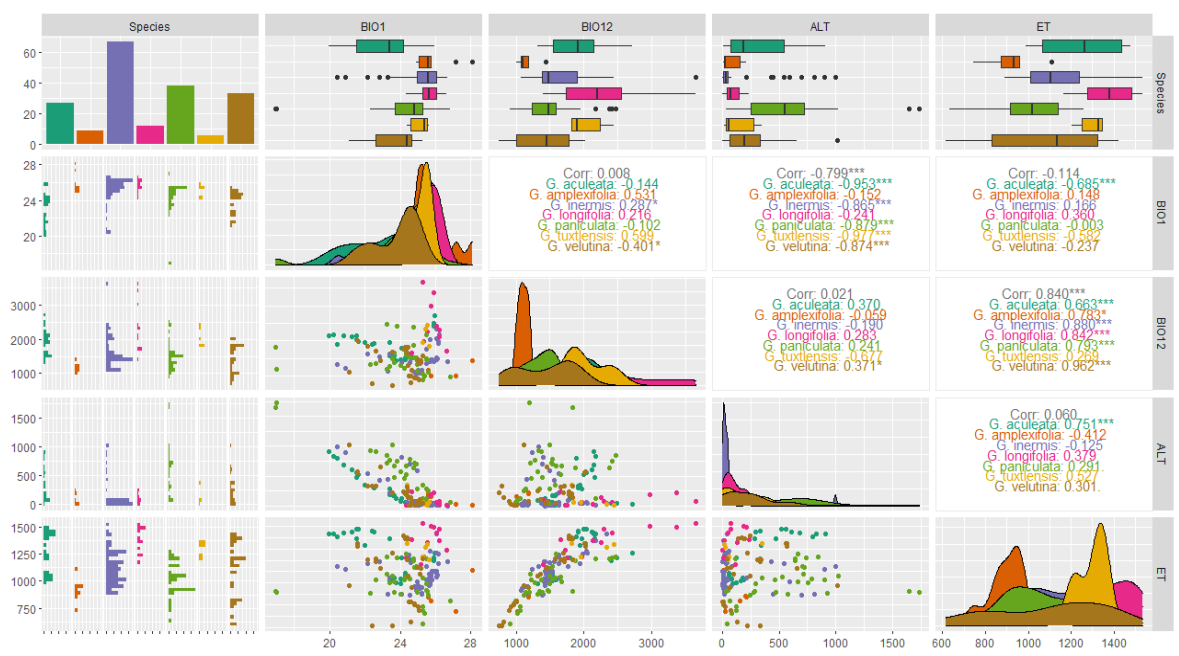

Figure 2: Boxplots, histograms, density plots, scatter plots and correlations of the mean annual temperature (BIO1), altitude (ALT), annual precipitation (BIO12) and annual evapotranspiration (ET) of seven bamboo species. $*=p<0.05, * *=p<0.01, * * *=p<0.001$.

Annual mean maximum temperature ranges between 25.3 (G. velutina) and $28.1{ }^{\circ} \mathrm{C}$ ( $G$. amplexifolia), minimum annual temperature between 16.9 and $24.9{ }^{\circ} \mathrm{C}$, and annual mean temperature between 22.9 and $25.8^{\circ} \mathrm{C}$. Regarding water requirements, G. amplexifolia is the species that requires the least annual precipitation $(1,111 \mathrm{~mm})$. Opposite case occurs in the distribution of $\mathrm{G}$. longifolia species (2,303 $\mathrm{mm}$ of average annual precipitation and $1,374 \mathrm{~mm}$ of 
average annual evapotranspiration). About annual evapotranspiration, G. velutina is the species with the lowest average annual evapotranspiration. Information about edaphoclimatic diversity of Guadua species is concentrated in Figure 3 where can be identify the proportion of each species respect to the climate type and soil unit in which each accession is distributed.

a

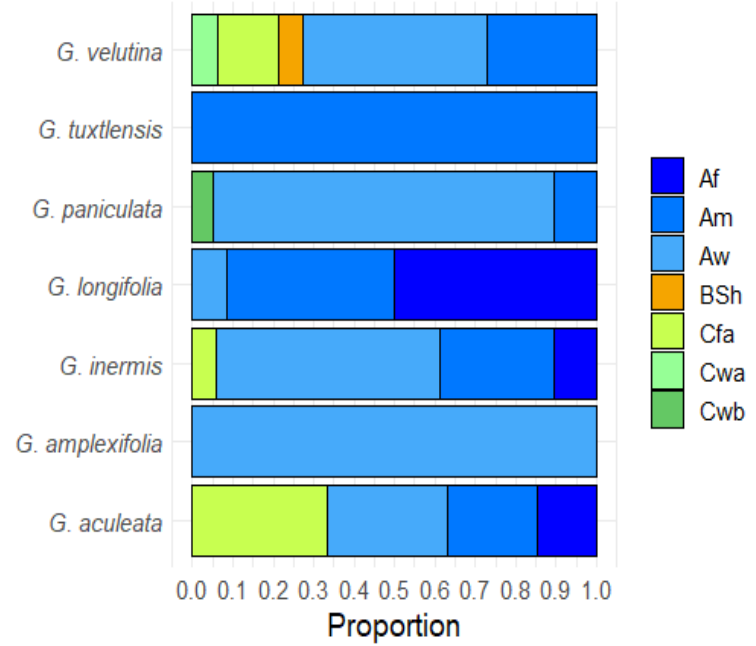

b

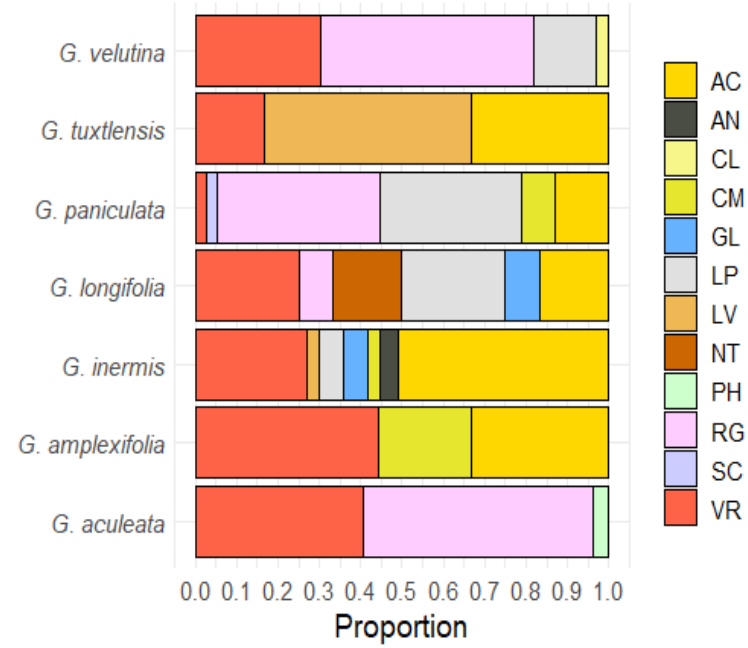

Figure 3: Climatic (a) and edaphic (b) diversity proportion of Guadua species. Climate type $=$ Af (Tropical, rainforest), Am (Tropical, monsoon), Aw (Tropical, Savannah), BSh (Arid, steppe, hot), Cfa (Temperate, no dry season, hot summer, Cwa (Temperate, dry winter, hot summer) y Cwb (Temperate, dry winter, warm summer); Soil unit = AC (Acrisol), AN (Andosol), CL (Calcisol), CM (Cambisol), GL (Gleysol), LP (Leptosol), LV (Luvisol), NT (Nitosl), PH (Phaeozem), RG (Regosol), SC (Solonchak) and VR (Vertisol).

Edaphic diversity of Guadua species is greater (12 soil units) respect to the diversity of climates (7 climate types) present in the same species. Regarding climates, bamboo species are distributed in eight of the 30 climates proposed by Beck et al. (2018) ${ }^{\text {[31] }}$ : Af, Am, Aw, BSh, Cfa, Cwa and $\mathrm{Cwb}$. Of these climate types, climates Am and Aw are the ones that occur most frequently, while the climates Cwa and $\mathrm{Cwb}$ are only found in one species $(G$. velutina and $G$. paniculata, respectively). Climatic diversity within each species, $G$. velutina is the species with the greatest diversity of climates (5), while G. tuxtlensis and G. amplexifolia are only located in one climatic type: Am for G. tuxtlensis and Aw for G. amplexifolia. Vertisol, acrisol and regosol predominate in distribution areas of the seven bamboo species studied. The less frequent soils units are calcisol (G. velutina), andosol (G. inermis), nitosol (G. longifolia) and phaeozem (G. aculeata). Soil diversity among species, G. tuxtlensis, G. amplexifolia and G. aculeata are the species with the lowest soil diversity ( 3 units). On the contrary, G. inermis is the species with the greatest soil diversity.

Tables 3 and 4 show the ecological descriptors of the seven bamboo species, grouping them according to climate type and soil unit. In these tables, the average values associated with the soil units and climatic types where each species is distributed can be identified. An example of this is the combination of $G$. paniculata with $\mathrm{Cwb}$ climate, having the lowest annual temperature and 
Vol. 06, No. 03; 2021

ISSN: $2456-8643$

the highest altitude. The opposite case occurs in G. amplexifolia associated with the Aw climate, where the highest annual temperature occurs.

\subsection{Statistical analysis}

Multicollinearity between variables of the environmental system was eliminated through a correlation analysis, where all those variables with absolute coefficients $>0.95$ were eliminated (BIO2, BIO8, BIO9, BIO10, BIO14, BIO16, BIO17, TEB, CASO4 and Sodicity) with a total of 25 edaphoclimatic variables to run the statistical analyses.

The PCA gave as result that it is possible to explain $81.6 \%$ of the total variation with only two principal components (PC). PC1 contributed $43.1 \%$ of variation and is composed of variables related to precipitation: annual evapotranspiration (ET), annual precipitation (BIO12), precipitation of the coldest four-month period (BIO19), seasonal precipitation (BIO15) and precipitation of the wettest month (BIO13). On the other hand, PC2 (35.5\%) was made up of variables related to temperature: $\mathrm{BIO} 1$ (annual mean temperature), $\mathrm{BIO} 5$ (maximum temperature of the warmest month) and altitude (ALT). Figure 4 shows the biplot with the distribution of the variables used in the PCA and the distribution of the collections by species on the first two PCs. Figure 4a shows the distribution of temperature, precipitation and soil variables. It is observed that most of the variables related to precipitation are located in both upper quadrants (except BIO15), temperature variables are located in the left quadrants (with the exception of altitude, $\mathrm{BIO} 3$ and $\mathrm{BIO} 7$, located in the lower right quadrant) and soil variables are distributed in all quadrants.

The distribution of the seven bamboo species studied with respect to principal components is shown in Figure 4b. In this figure, it can be seen that $G$. paniculata is the only species that showed a distribution pattern where there are no transition zones or overlap between the rest of the species. This information agrees with the geographic distribution of the G. paniculata accessions located mostly in the western part of Mexico.

CA resulted in the formation of six clusters.

a

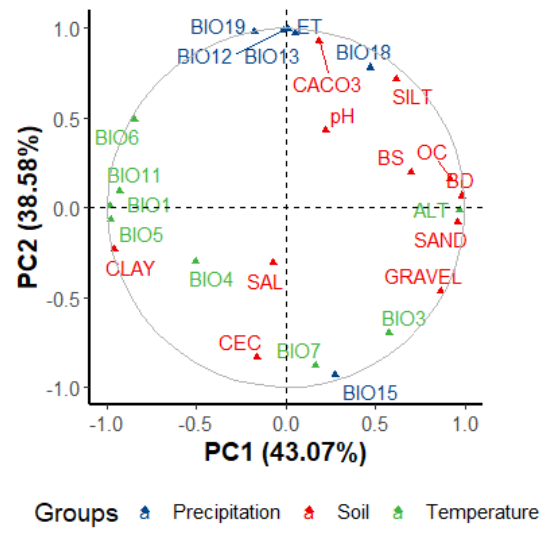

b

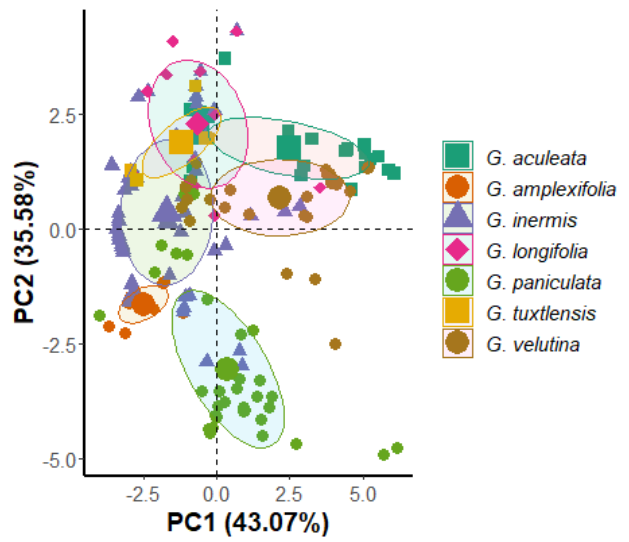

Figure 4: a) Biplot of precipitation, temperature and soil variables on the first two PC. b) Distribution of the accessions of seven bamboo species on the first two PC. 
Figure 5 shows the distribution of each cluster, as well as the proportion of accessions of each species for the formation of these six groups.

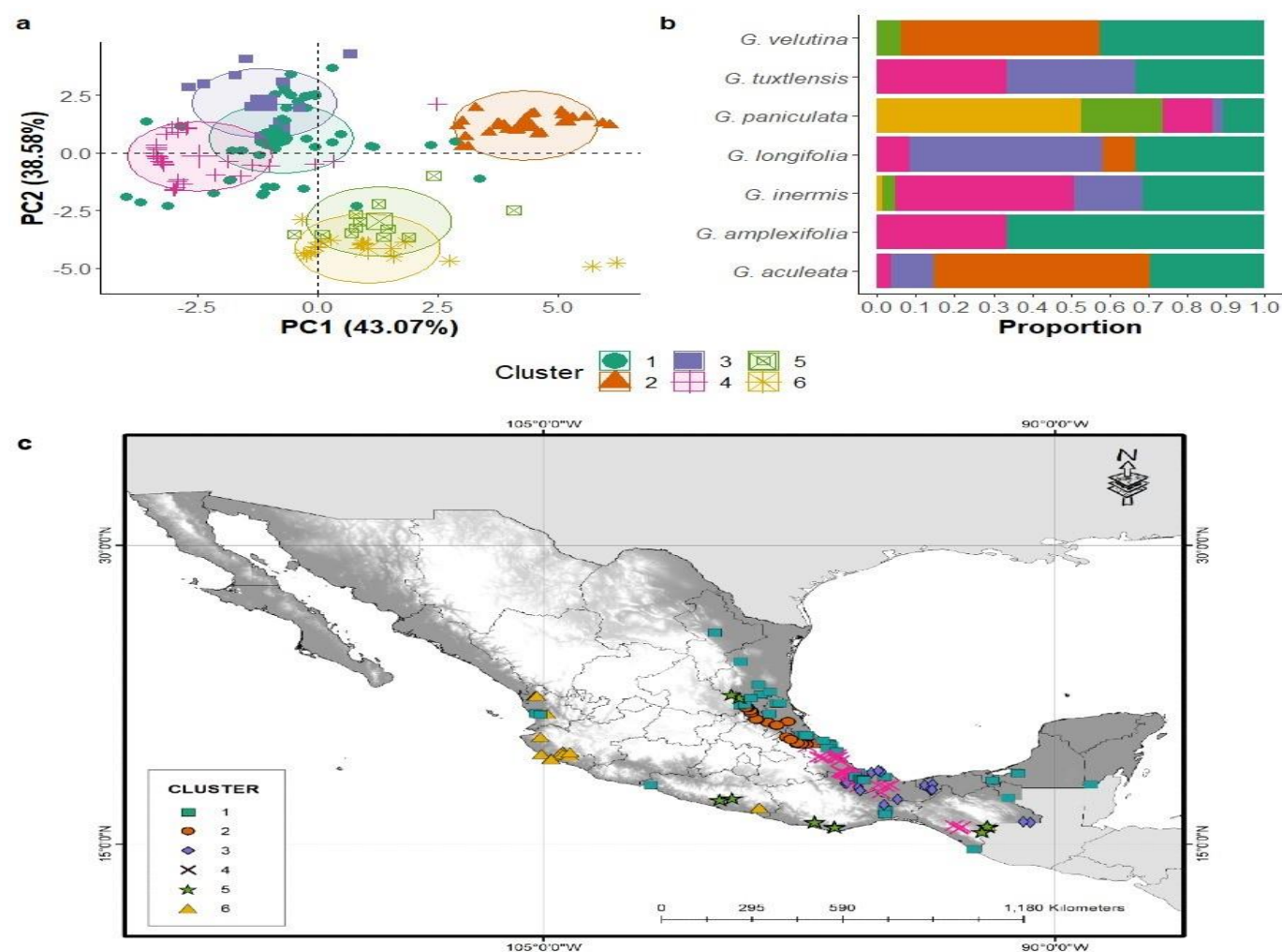

Figure 5: Groups formed by CA from 25 edaphoclimatic variables with Euclidean distances and Ward's grouping method. a) Cluster distribution according to the first $2 \mathrm{CPs}$, b) Proportion of accessions in the contribution of each cluster, c) Geographic distribution of the clusters identified by the CA.

Table 5. Average values of eight edaphoclimatic variables and Tukey's mean comparison test for the six clusters identified with $\mathrm{CA}$. BIO1= mean annual temperature $\left({ }^{\circ} \mathrm{C}\right)$, ALT $=$ altitude $(\mathrm{m})$, BIO12 $=$ annual precipitation $(\mathrm{mm}), \mathrm{ET}=$ annual evapotranspiration $(\mathrm{mm})$, $\mathrm{BD}=$ bulk density $\left(\mathrm{kg} / \mathrm{dm}^{3}\right), \mathrm{pH}, \mathrm{CEC}=$ cation exchange capacity $(\mathrm{cmol} / \mathrm{kg}), \mathrm{SB}=$ percentage of bases $(\%)$.

\begin{tabular}{|ccccccccc|}
\hline Cluster & BIO1 & ALT & BIO12 & ET & BD & pH & CEC & SB \\
\hline $\mathbf{1}$ & $24.8 \mathrm{AB}$ & $114 \mathrm{C}$ & $1,374 \mathrm{C}$ & $1,030 \mathrm{BC}$ & $1.30 \mathrm{DE}$ & $7.5 \mathrm{~B}$ & $27.1 \mathrm{~B}$ & $97.7 \mathrm{~A}$ \\
$\mathbf{2}$ & $22.8 \mathrm{C}$ & $352 \mathrm{~B}$ & $1,843 \mathrm{~B}$ & $1,321 \mathrm{~A}$ & $1.56 \mathrm{~B}$ & $8.0 \mathrm{~A}$ & $18.0 \mathrm{CD}$ & $100.0 \mathrm{~A}$ \\
$\mathbf{3}$ & $25.8 \mathrm{~A}$ & $60 \mathrm{C}$ & $2,478 \mathrm{~A}$ & $1,358 \mathrm{~A}$ & $1.33 \mathrm{D}$ & $6.6 \mathrm{C}$ & $20.3 \mathrm{C}$ & $86.4 \mathrm{~B}$ \\
$\mathbf{4}$ & $24.7 \mathrm{AB}$ & $211 \mathrm{BC}$ & $1,564 \mathrm{C}$ & $1,092 \mathrm{~B}$ & $1.27 \mathrm{E}$ & $4.7 \mathrm{E}$ & $15.0 \mathrm{DE}$ & $44.0 \mathrm{C}$ \\
$\mathbf{5}$ & $24.0 \mathrm{BC}$ & $636 \mathrm{~A}$ & $1,322 \mathrm{C}$ & $1,019 \mathrm{BC}$ & $1.39 \mathrm{C}$ & $7.7 \mathrm{AB}$ & $44.0 \mathrm{~A}$ & $100.0 \mathrm{~A}$ \\
$\mathbf{6}$ & $23.9 \mathrm{BC}$ & $592 \mathrm{~A}$ & $1,391 \mathrm{C}$ & $952 \mathrm{C}$ & $1.65 \mathrm{~A}$ & $6.0 \mathrm{D}$ & $13.1 \mathrm{E}$ & $75.1 \mathrm{~B}$ \\
\hline
\end{tabular}


Medians with the same letter within each column are not statistically different $(\mathrm{p} \leq 0.05)$ according to the multiple comparisons and Tukey test.

Table 5 shows the average values of eight edaphoclimatic variables and Tukey mean comparison test for the clusters identified in the CA. Cluster 1 is composed of accessions of all species with a majority of Aw climate type, is distributed in the Gulf Coast region and Chiapas with some accessions in the Pacific region, characterized by mean annual temperature of $24.8^{\circ} \mathrm{C}$, altitude of 114 masl and $1,374 \mathrm{~mm}$ of annual precipitation with moderately basic soils $(\mathrm{pH}=7.5)$.

Cluster 2 consists mainly of accessions of $G$. aculeata. The species in this group are mainly distributed in the Gulf Coast region. The species of this group are those with the lowest mean annual temperature $\left(22.8^{\circ} \mathrm{C}\right)$ and the highest soil $\mathrm{pH}$ value (8.0).

Species in cluster 3 are mainly distributed in the southern Gulf Coast region and the majority of $G$. longifolia accessions are found in this group. This group of species is characterized by presenting mean annual temperature of $25.8^{\circ} \mathrm{C}$, lower altitude distribution $(60 \mathrm{~m})$ and greater water availability $(2,478 \mathrm{~mm})$.

Cluster 4 is distributed in the Gulf Coast region, extending to Chiapas. G. inermis mostly integrates cluster 4 . The species in cluster 4 are those that have edaphic characteristics with lower values such as strongly acidic soils (4.7), the lowest percentage of bases and bulk density. Finally, cluster 5 and 6 are distributed in the Pacific coast region. Both and mainly made up of accessions of $G$. paniculata. This clusters are characterized by having accessions with the highest altitude distribution and in distribute in areas with little amount of annual precipitation.

\section{DISCUSSION}

Bamboo is a forest species with a large number of potential uses, such as construction, fibres, food and combustion, ornamental ${ }^{[38]}$, and with great ecological importance as having a great capacity to capture carbon ${ }^{[39]}$. Therefore, there are many species of bamboo with a great diversity of climatic requirements for their growth, making it difficult to characterize optimal requirements for their establishment ${ }^{[40]}$.

Variables considered in the general climatic descriptors reported in Table 2 (mean annual temperature, altitude, accumulated precipitation and annual evapotranspiration) are important to identify the patterns that determine the distribution of the studied bamboo species. Precipitation affects the distribution and growth limits of bamboo more than any other climatic component, with the exception of temperature. In India, $61 \%$ of bamboo species are located in areas with annual precipitation of 1,500 to $4,000 \mathrm{~mm}^{[41]}$.

In addition to the high-water requirements, the availability of water during specific growth stages affects the productivity of bamboo ${ }^{[42]}$.

Battisti et al. (2019) ${ }^{[40]}$ identified as optimal values for the establishment of bamboo optimal mean annual temperature of 15.1 to $35.3{ }^{\circ} \mathrm{C}$, minimum temperature of $12.0{ }^{\circ} \mathrm{C}$ and maximum temperature of $38.8^{\circ} \mathrm{C}$. The results obtained in the present investigation as ecological descriptors (Table 2) are within these ranges for all the seven species studied.

Regarding precipitation for bamboo cultivation and growing, Battisti et al. (2019) ${ }^{[40]}$ determined a minimum value of $775 \mathrm{~mm}$ per year, a maximum of $1,320 \mathrm{~mm}$ and a wet period of 8 months per year. In this regard, the ecological descriptors on annual precipitation (Table 2), exceed the 
values reported in the literature. This research also provides the annual evapotranspiration ranges, as an indicator of the cycle and water balance.

Despite the immense diversity of soils and the complex interactions between the physicochemical parameters and soil characteristics, it is difficult to relate bamboo growth to specific edaphic factors. Table 3 and 4 show the climate and soil descriptors related to the diversity of climate types and soil units of each bamboo species.

Table 3. Average values of edaphoclimatic variables according to climate types by bamboo species in Mexico. BIO1= annual mean temperature $\left({ }^{\circ} \mathrm{C}\right), \mathrm{ALT}=$ altitude $(\mathrm{m}), \mathrm{BIO12}=$ annual precipitation $(\mathrm{mm}), \mathbf{E T}=$ annual evapotranspiration $(\mathrm{mm}), \mathrm{BD}=$ bulk density $(\mathrm{kg} /$ $\left.\mathrm{dm}^{3}\right), \mathrm{pH}, \mathrm{CEC}=$ cation exchange capacity $(\mathrm{cmol} / \mathrm{kg}), \mathrm{SB}=$ percentage of bases $(\%)$. Climate types= Af (Tropical, rainforest), Am (Tropical, monsoon), Aw (Tropical, Savannah), BSh (Arid, steppe, hot), Cfa (Temperate, no dry season, hot summer), Cwa (Temperate, dry winter, hot summer) and Cwb (Temperate, dry winter, warm summer).

\begin{tabular}{|c|c|c|c|c|c|c|c|c|c|}
\hline Species & Climate & BIO1 & ALT & BIO12 & ET & BD & pH & CEC & SB \\
\hline \multirow{4}{*}{ G. aculeata } & Af & 23.1 & 260 & 1,897 & 1,382 & 1.4 & 8.0 & 20.7 & 100 \\
\hline & Am & 24.7 & 88 & 2,102 & 1,212 & 1.4 & 7.6 & 21.3 & 100 \\
\hline & Aw & 23.8 & 119 & 1,496 & 1,043 & 1.3 & 8.0 & 26.5 & 100 \\
\hline & Cfa & 20.8 & 698 & 2,092 & 1,493 & 1.5 & 7.8 & 18.0 & 98.8 \\
\hline G. amplexifolia & Aw & 25.8 & 76 & 1,140 & 917 & 1.3 & 6.1 & 18.1 & 79.4 \\
\hline \multirow{4}{*}{ G. inermis } & Af & 25.7 & 37 & 2,400 & 1,403 & 1.3 & 5.8 & 19.0 & 71.2 \\
\hline & Am & 25.3 & 87 & 1,903 & 1,239 & 1.3 & 6.2 & 23.5 & 75.5 \\
\hline & Aw & 25.3 & 92 & 1,352 & 1,013 & 1.3 & 5.8 & 20.9 & 68.2 \\
\hline & $\mathrm{Cfa}$ & 20.5 & 971 & 1,309 & 1,140 & 1.2 & 4.7 & 15.0 & 43.0 \\
\hline \multirow{3}{*}{ G. longifolia } & Af & 25.5 & 93 & 2,718 & 1,492 & 1.2 & 6.7 & 20.0 & 81.3 \\
\hline & Am & 25.6 & 99 & 1,985 & 1,349 & 1.3 & 6.9 & 24.8 & 88.6 \\
\hline & Aw & 25.1 & 113 & 1,399 & 1,166 & 1.3 & 7.5 & 35.0 & 100 \\
\hline \multirow{3}{*}{ G. paniculata } & $\mathrm{Am}$ & 24.4 & 440 & 2,255 & 1,222 & 1.2 & 5.3 & 16.5 & 57.2 \\
\hline & Aw & 24.6 & 475 & 1,407 & 986 & 1.5 & 6.4 & 22.3 & 86.2 \\
\hline & Cwb & 16.9 & 1,690 & 1,514 & 922 & 1.5 & 6.0 & 11.0 & 100.0 \\
\hline G. tuxtlensis & $\mathrm{Am}$ & 25.1 & 142 & 2,040 & 1,296 & 1.2 & 6.5 & 24.0 & 78.0 \\
\hline \multirow{5}{*}{ G. velutina } & Am & 23.8 & 229 & 1,768 & 1,343 & 1.5 & 8.0 & 18.0 & 100.0 \\
\hline & Aw & 24.7 & 78 & 1,171 & 937 & 1.3 & 7.9 & 26.6 & 100.0 \\
\hline & BSh & 22.9 & 278 & 768 & 614 & 1.3 & 8.2 & 18.0 & 100.0 \\
\hline & Cfa & 21.8 & 475 & 1,949 & 1,285 & 1.5 & 8.0 & 18.0 & 100.0 \\
\hline & Cwa & 21.9 & 838 & 1,282 & 1,054 & 1.3 & 7.6 & 32.0 & 100.0 \\
\hline
\end{tabular}


Table 4. Average values of edaphoclimatic variables associated with soil units by bamboo species in Mexico. BIO1= annual mean temperature $\left({ }^{\circ} \mathrm{C}\right), \mathrm{ALT}=$ altitude $(\mathrm{m}), \mathrm{BIO12}=$ annual precipitation $(\mathrm{mm}), \mathbf{E T}=$ annual evapotranspiration $(\mathrm{mm}), \mathrm{BD}=$ bulk density $(\mathrm{kg} /$ $\left.\mathrm{dm}^{3}\right), \mathrm{pH}, \mathrm{CEC}=$ cation exchange capacity $(\mathrm{cmol} / \mathrm{kg}), \mathrm{SB}=$ percentage of bases $(\%)$. Climate types= Af (Tropical, rainforest), Am (Tropical, monsoon), Aw (Tropical, Savannah), BSh (Arid, steppe, hot), Cfa (Temperate, no dry season, hot summer), Cwa (Temperate, dry winter, hot summer) and $\mathrm{Cwb}$ (Temperate, dry winter, warm summer).

\begin{tabular}{|c|c|c|c|c|c|c|c|c|c|}
\hline Species & Soil & BIO1 & ALT & BIO12 & ET & BD & pH & CEC & SB \\
\hline \multirow{3}{*}{ G. aculeata } & $\mathrm{PH}$ & 20.5 & 799 & 1,896 & 1,413 & 1.3 & 6.4 & 18.0 & 90.0 \\
\hline & $\mathrm{RG}$ & 22.0 & 451 & 1,936 & 1,349 & 1.6 & 8.0 & 18.0 & 100.0 \\
\hline & VR & 24.4 & 112 & 1,825 & 1,126 & 1.3 & 7.8 & 26.8 & 100.0 \\
\hline \multirow{3}{*}{ G. amplexifolia } & $\mathrm{AC}$ & 25.1 & 21 & 1,117 & 959 & 1.3 & 4.7 & 15.0 & 43.0 \\
\hline & $\mathrm{CM}$ & 27.6 & 18 & 1,227 & 928 & 1.4 & 6.4 & 17.0 & 93.0 \\
\hline & $\mathrm{RG}$ & 25.5 & 148 & 1,115 & 882 & 1.4 & 7.2 & 21.0 & 100.0 \\
\hline \multirow{7}{*}{ G. inermis } & $\mathrm{AC}$ & 25.0 & 154 & 1,536 & 1,096 & 1.3 & 4.7 & 15.0 & 43.0 \\
\hline & AN & 23.2 & 338 & 1,564 & 1,178 & 1.6 & 6.4 & 38.0 & 80.0 \\
\hline & $\mathrm{CM}$ & 26.1 & 12 & 1,493 & 1,059 & 1.2 & 6.8 & 23.0 & 89.0 \\
\hline & GL & 26.2 & 9 & 1,803 & 1,260 & 1.3 & 6.7 & 33.5 & 92.5 \\
\hline & LP & 25.7 & 326 & 1,505 & 1,095 & 1.4 & 7.6 & 39.5 & 100.0 \\
\hline & LV & 24.8 & 414 & 1,927 & 1,120 & 1.4 & 6.8 & 21.5 & 91.0 \\
\hline & VR & 25.3 & 41 & 1,737 & 1,159 & 1.3 & 7.4 & 22.8 & 100.0 \\
\hline \multirow{6}{*}{ G. longifolia } & $\mathrm{AC}$ & 25.7 & 50 & 2,197 & 1,340 & 1.3 & 4.7 & 15.0 & 43.0 \\
\hline & GL & 26.2 & 22 & 2,133 & 1,375 & 1.4 & 5.7 & 19.0 & 85.0 \\
\hline & LP & 26.0 & 63 & 1,810 & 1,312 & 1.3 & 7.5 & 35.0 & 100.0 \\
\hline & NT & 25.8 & 199 & 3,178 & 1,498 & 1.2 & 7.3 & 18.0 & 80.0 \\
\hline & $\mathrm{RG}$ & 24.7 & 237 & 1,660 & 1,382 & 1.6 & 8.0 & 18.0 & 100.0 \\
\hline & VR & 25.1 & 73 & 2,555 & 1,373 & 1.3 & 7.5 & 23.7 & 100.0 \\
\hline \multirow{6}{*}{ G. paniculata } & $\mathrm{AC}$ & 24.4 & 586 & 2,221 & 1,216 & 1.3 & 4.7 & 15.0 & 43.0 \\
\hline & $\mathrm{CM}$ & 25.4 & 191 & 1,283 & 893 & 1.3 & 6.5 & 19.0 & 91.7 \\
\hline & LP & 22.8 & 821 & 1,382 & 1,007 & 1.5 & 7.0 & 31.3 & 100.0 \\
\hline & RG & 25.0 & 402 & 1,368 & 953 & 1.7 & 6.0 & 14.0 & 80.0 \\
\hline & $\mathrm{SC}$ & 25.5 & 53 & 1,469 & 931 & 1.2 & 9.0 & 33.0 & 100.0 \\
\hline & VR & 25.5 & 117 & 2,169 & 1,213 & 1.4 & 7.2 & 21.0 & 100.0 \\
\hline \multirow{3}{*}{ G. tuxtlensis } & $\mathrm{AC}$ & 25.5 & 57 & 1,904 & 1,215 & 1.3 & 4.7 & 15.0 & 43.0 \\
\hline & LV & 24.8 & 237 & 2,030 & 1,344 & 1.3 & 7.5 & 31.0 & 94.0 \\
\hline & VR & 25.4 & 30 & 2,344 & 1,316 & 1.4 & 7.2 & 21.0 & 100.0 \\
\hline \multirow{4}{*}{ G. velutina } & $\mathrm{CL}$ & 22.4 & 336 & 790 & 614 & 1.5 & 8.4 & 7.0 & 100.0 \\
\hline & LP & 23.6 & 466 & 1,378 & 1,090 & 1.3 & 7.6 & 29.6 & 100.0 \\
\hline & RG & 23.5 & 271 & 1,772 & 1,294 & 1.6 & 7.0 & 18.0 & 100.0 \\
\hline & VR & 24.6 & 57 & 953 & 786 & 1.2 & 8.0 & 29.0 & 100.0 \\
\hline
\end{tabular}


In general, it is recognized that bamboo grows in areas with "poor" soils ${ }^{[43]}$, so it is used for the rehabilitation of degraded soils ${ }^{[44]}$. Among the physical factors of soil that influence the productivity of bamboo are the slope, texture, bulk density, moisture storage capacity and soil temperature ${ }^{[42]}$.

Among chemical properties of soils, the availability of nutrients, $\mathrm{pH}$ and salinity are the most important properties that mark the productivity and growth of bamboo plantations. Compared to other crops, bamboo is less affected by acidic soils, making them suitable for cultivation on degraded lands in tropical and subtropical regions where soils are frequently flooded and therefore with low $\mathrm{pH}$. Bamboos generally do not tolerate salty conditions in the soil ${ }^{[42]}$.

There are no studies about the edaphoclimatic diversity of the sites where Guadua species studied are distributed. The closest approach is the work done by Ruiz-Sanchez et al. (2020) ${ }^{[11]}$ about the diversity and endemism of native bamboos of Mexico. In this work the authors define diversity using physiographic provinces, biogeographic regions and political division, concluding that the greatest diversity of bamboos is located in the Mexican transition zone, followed by the neotropical region.

One of the species with less climatic and edaphic variability is $G$. tuxtlensis, a fact attributable to the geographic isolation in the area of Los Tuxtlas where it is located with an age of 16,000 to 1.92 million years ${ }^{[45]}$. This species is partially sympatric with $G$. inermis that grows in the coastal plain to the northwest of Los Tuxtlas region. G. tuxtlensis shares morphological characters with G. aculeata and G. inermis ${ }^{[46]}$.

The present work successfully identified edaphic and climatic variables with the greatest association and importance for distribution of bamboo species under study (Figure 4 and 5). Multivariate analysis techniques are very useful to identify patterns between sets of variables. In this regard, there are few works where the benefits of these statistical techniques are used to bamboo species, or data with which the results obtained can be compared.

An example of a study using multivariate techniques is that carried out by Cifuentes and Mejía (2013) ${ }^{[47]}$ with a multivariate characterization through the use of principal components with morphological variables. Another interesting example is the one carried out by Marulanda et al. (2002) ${ }^{[48]}$ with the use of principal components and cluster analysis for data obtained with molecular markers.

There are several examples of research in other plant species where multivariate statistics are used to identify patterns of association between variables, such the one made for Ruíz-Corral et al. (2013) ${ }^{[49]}$ in corn, Sánchez-González et al. (2018) ${ }^{[22]}$ in teocinte, Ramírez-Ojeda et al. (2021) ${ }^{[50]}$ on wild tomatoes, to name a few.

The findings of this work constitute a basis on the edaphic and climatic requirements of some of the native bamboo species distributed in Mexico. This information is of utmost importance for the identification of ecological characteristics and distribution environments in which the evaluated species can thrive optimally. The results can be used to identify potential areas of establishment of the species for commercial purposes.

In addition, this information can be used in order to generate strategies for the conservation and identification of material in danger of extinction due to climate change or with potential use as a source of germplasm for the development of new varieties of bamboo adapted to specific edaphoclimatic conditions. 
Vol. 06, No. 03; 2021

ISSN: $2456-8643$

This work is only a small part of the ecogeographic characterization of the Mexican native bamboo species. It is worth mentioning that it is extremely important to continue with the evaluation of the environments and ecological patterns that determine the distribution of the native species of bamboo in Mexico.

\section{REFERENCES}

[1] Stamm J (2008). La evolución de los métodos constructivos en Bambú. Segundo Congreso Mexicano del Bambú, Puebla, México. Website http://www.bambumex.org/ArquitecturayBambuJorge\%20Stamm.pdf.

[2] Cortés RG (2005). Etnobotánica de los bambúes de México. Biobambú 2(7). http://www.bambumex.org/paginas/ETNOBOTANICA.pdf (Accessed 25 febrero 2021).

[3] Vorontsova MS, Clark LG, Dransfield J, Govaerts R, Baker WJ (2016). World checklist of bamboos and rattans. Beijing: International Network of Bamboo \& Rattan.

[4] Soreng RJ, Peterson PM, Romaschenko K, Davidse G, Teisher JK, Clark LG, Barberá P, Gillespie LJ (2017). A worldwide phylogenetic classification of the Poaceae (Gramineae): II An update and a comparison of two 2015 classifications. Journal of Systematic and Evolution 55: 259-290. doi:10.1111/jse.12262

[5] Clark LG, Oliveira RP (2018). Diversity and evolution of the New World bamboos (Poaceae: Bambusoideae: Bambuseae, Olyreae). In: The World Bamboo Organization (editors). Proceedings of the 11th World Bamboo Congress, Xalapa, Mexico. Plymouth: The World Bamboo Organization, pp. 35-47.

[6] BPG (Bamboo Phylogeny Group) (2012). An updated tribal and subtribal classification of the bamboos (Poaceae: Bambusoideae). Bamboo Science and Culture 1: 1-10. http://www.bamboo.org/publications/e107_files/downloads/BSCv25-LR.pdf (Accessed 15 febrero 2021).

[7] Clark LG, Londoño X, Ruiz-Sánchez E (2015). Bamboo taxonomy and habitat. In: Liese W, Köhl M (editors). Bamboo: the plant and its uses (tropical forestry). 1st ed. Switzerland: Springer International Publishing, pp. 1-30.

[8] Ruiz-Sánchez E, Clark LG, Londoño X, Mejía-Saulés T, Cortés-Rodríguez G (2015). Morphological keys to the genera and species of bamboos (Poaceae: Bambusoideae) of Mexico. Phytotaxa 236: 1-24. doi:10.11646/phytotaxa.236.1.1

[9] Ruiz-Sanchez E, Tyrrel CD, Londoño X, Oliveira RP, Clark LG (2021a). Diversity, distribution, and classification of Neotropical woody bamboos (Poaceae: Bambusoideae) in the 21st Century. Botanical Sciences 99(2): 198-228. doi:10.17129/botsci.2722

[10] Dávila P, Mejia-Saulés MT, Soriano-Martínez AM, Herrera-Arrieta Y (2018). Conocimiento taxonómico de la familia Poaceae en México. Botanical Sciences 96: 462-514. doi:10.17129/botsci.1894

[11] Ruiz-Sánchez E, Munguía-Lino G, Vargas-Amado G, Rodríguez A (2020). Diversity, endemism and conservation status of native Mexican woody bamboos (Poaceae: Bambusoideae: Bambuseae). Botanical Journal of the Linnean Society 192(1): 281-295. doi: 10.1093/botlinnean/boz062

[12] Pérez-Alquicera J, Aguilera-López S, Rico Y, Ruiz-Sánchez E (2021a). A population genetics study of three native Mexican woody bamboo species of Guadua (Poaceae: 
Vol. 06, No. 03; 2021

ISSN: $2456-8643$

Bambusoideae: Guaduinae) using nuclear microsatellite markers. Botanical Sciences 99. doi: 10.17129/botsci.2795

[13] Ruiz-Sánchez E, Tyrrel CD, Vigosa JL (2021b). An overlooked new Rhipidocladum species endemic to Mexico. Systematic Botamy. In press.

[14] Ruiz-Sánchez E, Castro-Castro A, Zamora-Tavares MP (2021c). Molecular and morphological data support the recognition of a new species of Otatea (Poaceae: Bambusoideae: Guaduinae) from Durango, Mexico. Taxon. doi:10.1002/tax.12462

[15] Ruiz-Sánchez E, Romero-Guzmán R, Flores-Argüelles A, Ortiz-Brunel JP, Clark LG (2021d). Chusqueacontrerasii and C. guzmanii (Poaceae, Bambusoideae, Bambuseae, Chusqueinae), two new endemic species from Jalisco, Mexico. Phytotaxa 497(3): 285297. doi: $10.11646 /$ phytotaxa.497.3.7

[16] Carrillo-Avella Á, Ochoa-Gil VJ (2010). Estatus de la Guadua como material constructivo según concepto de los usuarios de los estratos. Revista Sophia 6: 140-150.

[17] Parra-Quijano M, Iriondo JM, Torres E (2012). Review. Applications of ecogeography and geographic information systems in conservation and utilization of plant genetic resources. Spanish Journal of Agricultural Research 10(2): 419-429. doi:10.5424/SJAR/2012102-303-11

[18] Hijmans JR, Spooner DM (2001). Geographic distribution of wild potato species. American Journal of Botany 88(11): 2101-2112. doi:10.2307/3558435

[19] Ruiz-Corral, JA, Sánchez-González JJ, Aguilar M (2001). Potential geographical distribution of teosinte in México: A GIS approach. Maydica 46(2): 105-110.

[20] López-Soto JL, Ruiz-Corral JA, Sánchez-González J de J, Lépiz-Idelfonso R (2005). Adaptación climática de 25 especies de frijol silvestre (Phaseolusspp.) en la República Mexicana. Revista Fitotecnia Mexicana 28(3): 221-230.

[21] Ruiz-Corral JA, Durán-Puga N, Sánchez-González JJ, Ron-Parra J, González-Eguiarte DR, Holland JB, Medina-García G (2008). Climatic adaptation and ecological descriptors of 42 Mexican maize (Zeamays L.) races. Crop Sciences 48(4): 1502-1512. doi:10.2135/cropsci2007.09.0518

[22] Sánchez-González JJ, Ruiz-Corral JA, Medina-García G, Ramírez-Ojeda G, de la Cruz-1 Larios L, Holland JB, Miranda-Medrano R, García-Romero GE (2018). Ecogeography of teosinte. PLoS ONE 13: e0192676. doi:10.1371/journal.pone.0192676

[23] Steiner JJ, Greene SL (1996). Proposed ecological descriptors and their utility for plant germplasm collections. Crop Science 36(2): 439-451. doi:10.2135/cropsci1996.0011183X003600020037x

[24] Ramírez-Ojeda G, Ruiz-Corral JA, Pérez-Mendoza C, Villavicencio-García R, MenaMunguía S, Durán-Puga N (2014). Impactos del cambio climático en la distribución geográfica de Gossypiumhirsutum L. en México. Revista Mexicana de CienciasAgrícolas 5(10):1885-1895.

[25] Lobo-Burle M, Torres-Cordeiro CM, Fonseca JR, Martins-Palhares RA, de Melo LA, Belem-das R, Abadie $T$ (2003). Characterization of germplasm according to environmental conditions at the collecting site using GIS: Two case studies from Brazil. Plant Genetic Resources Newsletter 135: 1-11.

[26] CONABIO (comp.) 2021. Catálogo de autoridades taxonómicas de especies de flora y fauna con distribución en México. Base de datos SNIB-CONABIO, México. 
Vol. 06, No. 03; 2021

ISSN: $2456-8643$

[27] GBIF (2021). Global Biodiversity Information Facility [online]. Website https://www.gbif.org/ [accessed 20 January 2021].

[28] Fick SE and RJ Hijmans (2017). WorldClim 2: new $1 \mathrm{~km}$ spatial resolution climate surfaces for global land areas. International Journal of Climatology 37(12): 4302-4315.

[29] Trabucco A, Zomer RJ (2019). Global High-Resolution Soil-Water Balance. Figshare. Fileset. doi: 10.6084/m9.figshare.7707605.v3

[30] FAO/IIASA/ISRIC/ISSCAS/JRC, 2009. Harmonized World Soil Database 1.1. Rome, Italy.

[31] Beck HE, Zimmermann NE, McVicar TR, Vergopolan N, Berg A, Wood E (2018). Present and future Köppen-Geiger climate classification maps at 1-km resolution. Scientific Data 5: 180214.

[32] R Core Team (2020). R: A language and environment for statistical computing. R Foundation for Statistical Computing. Vienna, Austria.

[33] Lê, S., Josse, J., Husson, F., 2008. FactoMineR: An R Package for Multivariate Analysis. Journal of Statistical Software 25, 1-18. https://doi.org/10.18637/jss.v025.i01

[34] Kassambara, A., 2017. Practical guide to Principal Component methods in R, First Edition. ed. STHDA.

[35] Yilan L, Rutong Z (2015). clustertend: check the clustering tendency. R package version 1.4. https://CRAN.R-project.org/package=clustertend.

[36] Brock G, Pihur V, Datta S, Datta S (2008). clValid: An R Package for Cluster Validation. Journal of Statistical Software 25: 1-22.

[37] Charrad M, Ghazzali N, Boiteau V, Niknafs A (2014). NbClust: An R Package for determining the relevant number of clusters in a data set. Journal of Statistical Software 61: 1-36. doi: 10.18637/jss.v061.i06

[38] Scurlock JMO, DC Dayton, B Hames (2000). Bamboo: an overlooked biomass resource. Biomass and Bioenergy 19(4): 229-244.

[39] Mao, F. J. et al. (2016). Development of the BIOME-BGCmodel for the simulation of managed Moso bamboo forestecosystems. Journal of Environmental Management172(1): 29-39.

[40] Battisti R, Casaroli J, Júnior A, Wagner M (2019). Agro-climatic zoning of bamboo as a support for crop farming in the central-north region of the Brazilian Savannah. Pesquisa Agropecuária Tropical 49, e52794. doi:10.1590/1983-40632019v4952794

[41] Biswas SAS (1988). Studies on bamboo distribution in northeastern region of India. The Indian Forester 114(9): 514-531

[42] Kleinhenz V, Midmore DJ (2001). Aspects of bamboo agronomy. Advances in Agronomy 74: 99-153. doi: 10.1016/S0065-2113(01)74032-1

[43] Sutiyono (1987). Silvicultural aspect of bamboo plantations in Kaliurang, Yogyakarta. BuletinPenelitianHutan 493:14-20.

[44] Rao KS, Maikhuri RK, Saxena KG (1999). Participatory approach to rehabilitation of degraded forestlands: a case study in a high-altitude village of Indian Himalaya. International Tree Crops Journal 10(1): 1-17. doi:10.1080/01435698.1999.9752988

[45] Ornelas JF, Sosa V, Soltis DE, Daza JM, González C, Soltis PS, Gutiérrez-Rodríguez C, Espinosa de los Monteros A, Castoe TA, Bell C, Ruiz-Sánchez E (2013). Comparative 
Vol. 06, No. 03; 2021

ISSN: $2456-8643$

phylogeographic analyses illustrate the complex evolutionary history of threatened cloud forest of northern Mesoamerica. PLoS ONE 8:e56283. doi:10.1371/journal.pone.0056283

[46] Londoño X, Ruíz-Sánchez E (2014). Guadua tuxtlensis (Poaceae: Bambusoideae: Bambuseae: Guaduinae), una nueva especie inadvertida de la región de los Tuxtlas, Veracruz, México. Botanical Sciences 92(4):481-488. doi: 10.17129/botsci.76

[47] Cifuentes X, Mejía LM, Ruiz JA (2013). Caracterización multivariante de la Guadua en el departamento del Quindío. UGCiencia (19): 128-142.

[48] Marulanda ML, Márquez P, Londoño X (2002). AFLP analysis of Guadua angustifolia (Poaceae: Bambusoideae) in Colombia with emphasis on the Coffee Region. The Journal of the American Bamboo Society 16(1): 32-42.

[49] Ruiz-Corral JA, Sánchez-González JJ, Hernández-Casillas JM, Willcox MC, RamírezOjeda G, Ramírez-Díaz JL, González-Eguiarte DR (2013). Identificación de razas de maíz adaptadas a condiciones deficientes de humedad mediante datos biogeográficos. Revista Mexicana de Ciencias Agricolas 4(6): 829-842. doi:10.29312/remexca.v4i6.1152

[50] Ramírez-Ojeda G, Peralta IE, Rodríguez-Guzmán E, Chávez-Servían JL, SahagúnCastellanos J, Rodríguez-Pérez JE (2021). Climatic diversity and ecological descriptors of wild tomato species (Solanum sect. Lycopersicon) and close Related species (Solanum sect. Juglandifolia y sect. Lycopersicoides) in Latin America. Plants 10(5): 855. doi: $10.3390 /$ plants 10050855 